\title{
PIIISGUC.ORG
}

"iş, GÜÇ" ENDÜSTRI iLişKILERI VE INSAN KAYNAKLARI DERGISi

"IS, GUC" INDUSTRIAL RELATIONS AND HUMAN RESOURCES JOURNAL

\section{Sosyo-Kültürel Yapının Üniversite Öğrencilerinin Bölüm Seçimi Üzerindeki Etkisi, Anadolu Üniversitesi Örneği}

\author{
Doç.Dr. Semra GÜNAY AKTAŞ, \\ Gökçe OFLí,
}

Gürkan BALABAN

University of Anadolu, Institute of Satellite and Space Sciences Research, İki Eylül Campus, Remote Sensing and GIS Department, ESKIŞEHIR

Ekim/October 2013, Cilt/Vol: 15, Sayı/Num: 4, Page: 59-71

ISSN: 1303-2860, DOI: 10.4026/1303-2860.2013.0237.x

Makalenin on-line kopyasına erişmek için / To reach the on-line copy of article: http://www.isguc.org/index.php?p=article\&id=542\&cilt=15\&sayi $=4 \& y i l=2013$

Makale İçin İletişim/Correspondence to:

Doç.Dr.Semra GÜNAY AKTAŞ / Email: semragunay@anadolu.edu.tr 


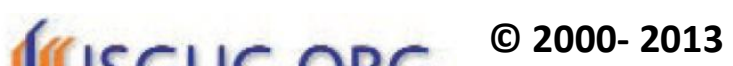 \\ "İş,Güç" Endüstri ilişkileri ve İnsan Kaynakları Dergisi "Işs,Güç" Industrial Relations and Human Resources Journal
}

\author{
Ekim/October 2013, Cilt/Vol: 15, Sayı/Num: 4, \\ Sayfa/Page: 59-71, DOI: 10.4026/1303-2860.2013.0237.x
}

"İş,Güç" Endüstri İlişkileri ve İnsan Kaynakları Dergisi, yılda dört kez yayınlanan hakemli, bilimsel elektronik dergidir. Çalışma hayatına ilişkin makalelere yer verilen derginin temel amact; belirlenen alanda akademik gelişime ve paylaşıma katkıda bulunmaktır.

"İş,Güç" Endüstri İlişkileri ve İnsan Kaynakları Dergisi'nde, 'Türkçe' ve 'İngilizce' olarak iki dilde makale yayınlanmaktadır. "İş,Güç" Endüstri İlişkileri ve İnsan Kaynakları Dergisi, ulusal ve uluslararası birçok indekste taranmaktadır. (Cabell's Directories, Ebsco Socindex, Index Islamicus, Index Copernicus International, Worldwide Political Science Abstracts, Sociological Abstract, Ulakbim Sosyal Bilimler Veritabanı, ASOS Index)

Editörler Kurulu / Editorial Board Aşkın Keser (Uludă̆ University) K.Ahmet Sevimli (Uludăg University) Şenol Baştürk (Uludağ University)

\section{Editör / Editor in Chief}

Şenol Baştürk (Uludăg University)

\section{Uygulama / Design}

Yusuf Budak (Kocaeli University)

Tarandığı Indeksler / Indexes ASOS INDEX

CABELL'S DIRECTORIES EBSCO SOCINDEX Index ISLAMICUS Index COPERNICUS Int. Sociological Abstract ULAKBİM Sosyal Bilimler Veritanı

Worldwide Political Science Abstracts

\author{
Yayın Kurulu / Editorial Board \\ Dr.Şenol Baştürk (Uludă̆ University) \\ Yrd.Doç.Dr.Zerrin Fırat (Uludă̆ University) \\ Doç.Dr.Aşkın Keser (Uludă̆ University) \\ Prof.Dr.Ahmet Selamoğlu (Kocaeli University) \\ Yrd.Doç.Dr.Ahmet Sevimli (Uludağ University) \\ Doç.Dr.Abdulkadir Şenkal (Kocaeli University) \\ Doç.Dr.Gözde Yılmaz (Marmara University) \\ Yrd.Doç.Dr.Memet Zencirkıran (Uludă̆ University)
}

Uluslararası Danışma Kurulu / International Advisory Board
Prof.Dr.Ronald Burke (York University - Kanada)
Assoc.Prof.Dr.Glenn Dawes (James Cook University - Avustralya)
Prof.Dr.Jan Dul (Erasmus University - Hollanda)
Prof.Dr.Alev Efendioğlu (University of San Francisco - ABD)
Prof.Dr.Adrian Furnham (University College London - Ingiltere)
Prof.Dr.Alan Geare (University of Otago - Yeni Zellanda)
Assoc. Prof. Dr. Diana Lipinskiene (Kaunos University - Litvanya)
Prof.Dr.George Manning (Northern Kentucky University - ABD)
Prof.Dr.Mustafa Özbilgin (Brunel University - UK)
Assoc. Prof. Owen Stanley (James Cook University - Avustralya)
Prof.Dr.Işık Urla Zeytinoğlu (McMaster University - Kanada)

Ulusal Danışma Kurulu / National Advisory Board

Prof.Dr.Yusuf Alper (Uludağ University)

Prof.Dr.Veysel Bozkurt (Ístanbul University)

Prof.Dr.Toker Dereli (Işık University)

Prof.Dr.Nihat Erdoğmuş (İstanbul Şehir University)

Prof.Dr.Ahmet Makal (Ankara University)

Prof.Dr.Süleyman Özdemir (İstanbul University)

Prof.Dr.Ahmet Selamoğlu (Kocaeli University)

Prof.Dr.Nadir Suğur (Anadolu University)

Prof.Dr.Nursel Telman (Maltepe University)

Prof.Dr.Cavide Uyargil (Istanbul University)

Prof.Dr.Engin Yildırım (Anayasa Mahkemesi)

Doç.Dr.Arzu Wasti (Sabancı University)

Dergide yayınlanan yazılardaki görüşler ve bu konudaki sorumluluk yazarlarına aittir.

Yayınlanan eserlerde yer alan tüm içerik kaynak gösterilmeden kullanılamaz.

All the opinions written in articles are under responsibilities of the authors.

The published contents in the articles cannot be used without being cited. 


\title{
Sosyo-Kültürel Yapının Üniversite Öğrencilerinin Bölüm Seçimi Üzerindeki Etkisi, Anadolu Üniversitesi Örneği
}

\author{
Doç.Dr. Semra GÜNAY AKTAŞ, \\ Gökçe OFLI, \\ Gürkan BALABAN
}

University of Anadolu, Institute of Satellite and Space Sciences Research, İki Eylül Campus, Remote Sensing and GIS Department, ESKİ̧EHİR

\begin{abstract}
In this study, the effects of socio-cultural structure on the department selection of the Anadolu University students have been researched. In the first part of the study, social, cultural, and socio-cultural structure features have been examined. In the next phase, after being determined what the socio-cultural structure elements are, the survey questions have been specified to solve the sub problems related to the base problem. In this study, Eskişehir university students as the universe of the research and also Anadolu University students as a sample have been chosen. As a result of this, the survey has been applied to the

Faculties of Literature, Engineering and Architecture, Economics and Administrative Sciences, and Fine Arts. The obtained data have been analysed in the SPSS programs, and it has been classified according to the cities where they lived before they won the university. Regional and local discrepancies have been determined by being mapped with the data obtained from the surveys and the CBS programme of socio-cultural outfits of the cities. Thus, at the end of the research, the effects of socio-cultural structure on the department selection of the Anadolu University students.
\end{abstract}

Key words: Socio-Cultural Structure, Department Selection, Socio-Cultural Maps, Geographical Information Systems, Anadolu University

\section{Özet}

Bu çalışmada sosyo-kültürel yapının Anadolu Üniversitesi öğrencilerinin bölüm seçimi üzerine olan etkileri ve öğrencilerin üniversiteyi kazandıktan sonra yaşamaya başladıkları şehrin ve üniversitenin sosyal ve kültürel olanaklarının sosyo-kültürel faaliyetlerine etkisi araştırılmıştır. Çalışmanın ilk kısmında sosyal yapı, kültürel yapı ve sosyo-kültürel yapı olguları incelenmiştir. Bir sonraki aşamada sosyo-kültürel yapı etmenlerinin neler olduğu belirlendikten sonra araştırmanın temel problemi kapsamında alt problemlere çözüm olacak şekilde anket soruları belirlenmiştir. Bu araştırmada Eskişehir ili Anadolu Üniversitesi öğrencileri araştırmanın evreni, örneklem olarak Anadolu Üniversitesi'nin Edebiyat, Mühendislik-Mimarlik, İktisadi İdari Bilimler, Güzel Sanatlar Fakülteleri seçilmiştir. Elde edilen veriler, SPSS programında analiz edilmiş ve öğrencilerin üniversiteyi kazanmadan önce yaşadıklarn illere göre sinıflanmıştır. Anketlerden elde edilen veriler ve illerin sosyokültürel donatıların CBS programı ile haritalanması ile bölgesel ve yöresel farklhliklar belirlenmiştir. Böylece araştırma sonunda sosyokültürel yapının Anadolu Üniversitesi öğrencilerinin bölüm seçimine olan etkileri belirlenmiştir.

Anahtar Kelimeler: Sosyo-ekonomik Yapl, Bölüm Seçimi, Harita, Coğrafi Bilgi Sistemi, Anadolu Üniversitesi 


\section{GIRIŞ}

Kişinin tutum ve davranışlarını sosyo kültürel yapı etkilemektedir. Eğitim, sosyal siniflar, danışma grupları, yüz yüze gruplar ve aile tarafından kişinin özellikleri etkilenmektedir. Sosyal yapıyı nüfusun özellikleri, yerleşme yerinin özellikleri ve fiziki çevrenin özellikleri, kültürel yapının değerleri ve inançlar meydana getirmektedir. Bütün bu özellikler dikkate alındığında bireyin yaşadığı yakın ve uzak çevre doğrudan etkili olmaktadır. Sosyal yapının iki farklı yönü olduğu anlaşılmaktadır. Bunlar (Çakır,2006);

a) Kültürel Yap1: Toplumun sosyal ilişkiler ağı dediğimiz sosyal statüler, roller ve değer yargilarından oluşan yapısı,

b) Fiziksel Yapı: Toplumun şekil ve çevresi olarak belirtilen dış görünüşünü oluşturan nüfusun yerleşim tarzı, fiziksel yapısını oluşturmaktadır. İçerisinde grupların, kurumların yer aldığı, sosyal ilişkilerin, sosyal olayların meydana geldiği, nüfus ve yerleşim tarzının şekillendirdiği, toplumun şekil ve çerçevesi ile ilgili dış görünüşe sahip olan sosyal yap1; toplumdan topluma, yöreden yöreye, tarihi, coğrafi, ekonomik yapı ve eğitim durumuna bağlı olarak farklıklar göstermektedir. Bu farklılıklar, şehirsel mekâna da yansımakta ve farklı mekânsal oluşumlara neden olmaktadırlar. Şehir mekânın kullanıcıları da bu özelliklerine bağlı olarak farklı konut alanlarını seçmeyi tercih etmektedirler.

Toplum bilimciler, sosyal yapının unsurlarını tanımladıklarında, bir toplum diğer bir toplumla karşılaştırılabilir hale gelir. Örneğin her toplumun aile yapısı, çocukların eğitimi ve toplumsal düzeni sağlayan kurumların yapısı birbirinden farklıdır. Bu yapılar ait oldukları toplum içinde, kendi aralarında anlamlı ve uyumlu bütünler haline geldikçe görevlerini uyumlu bütünler haline geldikçe görevlerini sürdürürler (Eroğlu, 1996).

Meriç'e göre "kültür, her ülkede ayrı libasa bürünen uçarı, serazat bir mefhum"dur. Turhan'a göre kültür ise, "bedeni, içtimai ve ruhi ihtiyaçların tatmininde rol oynayan vasitalar bütünüdür" (Meriç'ten akt. Aytekin, 2005). McGoldrick 'e göre kültür, bir grup insanın, dil, gelenek ve görenekle, değerler ve tavırlarla sonraki nesillere aktardığı yaşam biçimidir. Kültür, bireylerin davranışlarını, hedeflerini, düşüncelerini ve duygularını biçimlendirir (Mc Goldrick'ten akt. Sertelin, 2003). Kültür sözcügünün sosyolojik anlamı, bir toplumun tüm yaşam biçiminin ifadesidir. Çok basit bir anlatımla "Öğrenilmiş Davranışlar Bütünü" olarak ifade edilebilir (Aslan, 2001). Konu sosyo kültürel yapı şeklinde alınarak analize ve senteze tabi tutulduğunda bunun kültür öğelerinin ve kurumlarının zaman içinde tekrarlanarak meydana getirdikleri ve onların karşılıklı etkileşmeleri sonucunda çıkan sosyal dengeye verilen ad olduğu anlaşılmaktadır (Abbas, 2007).

Görüldüğü gibi SKY hem bulunan çevreden etkilenmekte, hem de bireyler bulundukları çevreyi etkilemektedir. Bu durum göz önünde bulundurulduğunda üniversite sinavinda alınan puanlar doğrultusunda bölüm tercihinin yapıldığı Türkiye'de öğrencilerin üniversite, fakülte ve bölüm tercihlerinde SKY özelliklerinin bir etkisinin olup olmadığ 1 sorusu ortaya çıkmaktadır. Bu araştırma Anadolu Üniversitesi öğrencileri örneğinde SKY ile bölüm tercihi arasında bir ilişkinin olup olmadığı sorusuna yanıt aramaktadır.

\section{YÖNTEM}

Araştırmada öğrencilerin sosyokültürel yapılarının bölüm tercihlerine bir etkisinin olup olmadığı sorusuna yanıt aranmıştır. Bu amaçla araştırmacılar tarafından bir sosyokültürel yapı ölçeği geliştirilmiştir. Öncelikle SKY ölçeği için bu konuda yapılmış araştırmalar incelenmiştir (Karasar, N., Hakan, A., Can, G., (1999), Kılınç, A. (2007), Pehlivan Baykara, K. (2008), Toğrul, İ., (2010) ve Abbas, Z. (2007)). Ölçek dört bölümden oluşmuştur. Kişisel bilgiler bölümünde aile fertlerinin eğitim durumları ve mesleklerine yönelik bilgiler, ekonomik durumla ilgili ikinci bölümde gelir ve yaşanılan konut hakkında bilgiler, üçüncü bölümde üniversite öncesi eğitim geçmişleri ile ilgili bilgiler ve dördüncü bölümde ise sosyal çevreleri hakkındaki bilgiler değerlendirilmiştir. Sosyal çevre ile ilgili bölümde öğrencilerin üniversiteyi kazanmadan önce ve kazandıktan sonra sosyal 
etkinlikleri ne sıklıkta yaptıkları sorulmuştur. "Her gün, haftada 2-3 gün, haftada bir gün, ayda bir, dönemlik (3-6 ayda bir), yılda bir ve hiç" şeklinde sıklık derecelendirmesi yapılmıştır. Öğrencilerin yanıtları "6 ila 0 " arasında puanlanmıştır. Ayrıca öğrencilerden yazılı ve sözlü basında takip ettikleri konular ve takip etme sıklıkları öğrenilmiştir. Sıklıklar yukarıda verildiği gibi derecelendirilmiştir. Buna ilaveten bilim ve teknik konuları ile haberler 5 ile, ekonomi, mesleki yayınlar ve politika 4 ile, spor, genel kültür yarışmaları 3 ile, sanat 2 ile, dizi, magazin 1 ile ağırlıklandırılmıştır. Her bir öğrencinin verdiği yanıtların toplanması ile bir sosyokültürel yapı (SKY) puanı bulunmuştur. $\mathrm{Bu}$ puanların aritmetik ortalaması ve standart sapması alınmıştır. 811 öğrencinin yanıt verdiği çalışmada öğrencilerin üniversiteyi kazanmadan önce SKY özelliklerinin aritmetik ortalaması 209, standart sapması 59,194'tür. Aritmetik ortalamaya standart sapmanın eklenmesiyle elde edilen değerin üstündeki puanlar üst grup, aritmetik ortalamadan standart sapmanin çıarılmasıyla elde edilen puanın altındaki değerler alt grup, aritmetik ortalama ve tstandart sapma aralığındaki değerler ise orta grup olarak sınıflanmıştır. Ayrıca hazırlanan ankette SKY ölçeği dışında öğrencilerin yaşadıkları yer, üniversiteyi kazanmadan önceki bazı özellikleri, üniversitede kazandıkları bölüme ilişkin görüşleri de alınmıştır.

Geliştirilen SKY sınıflamasına göre alt, orta ve üst SKY grupları arasında bölüm tercihi, geldikleri bölge gibi farklılıklar olup olmadığ1 araştırılmıştır. Anketler, 35 kişilik bir gruba ön uygulama yapılmış, gerekli düzenlemeler yapıldıktan sonra Anadolu Üniversitesi etik kurulun görüşü alınmıştır. Etik Kurul tarafından incelenen ve uzman görüşü alınan anket üzerinde tekrar düzenlemeler yapıldıktan sonra ana uygulama yapılmıştır. Anketler araştırmacılar tarafından İ̈BF, MMF, GSF ve Edebiyat fakültesinde ikinci sınıf öğrencilerine uygulanmıştır. Elde edilen veriler SPSS 17 paket programında analiz edilmiştir. Analiz edilen verilerin mekânsal dağılımlarını açıklamak için de Coğrafi Bilgi Sistemleri programı kullanılmıştır.
Ankete toplam 811 öğrenci görüş bildirmiştir. Öğrencilerin \%28.8'i İ̈BF, \%9.1'i GSF, \% 35'i Edebiyat Fakültesi, \% 27.1'i MMF okumaktadır. Araştırmaya görüş bildiren öğrencilerin \%63'ü kadın, \%37'si erkektir. Öğrencilerin \%12.5'i üniversiteyi kazanmadan önce Eskişehir'de yaşadıklarını bildirmiştir. Öğrencilerin \%95'i üniversiteyi kazanmadan önce şehir yerleşmelerinde, $\% 5^{\prime} \mathrm{i}$ ise kırsal yerleşmelerde yaşadıklarını bildirmişlerdir. Öğrenciler üniversiteyi kazanmadan önceki durumlarını bildirirken \%93'ü aileleriyle birlikte, \%2.6'sı annesiyle, \%0.4'ü babasiyla, $\% 0.9^{\prime} u$ tek başına, \%0.5'i de tek başına yaşadıklarını açıklamıştır. Öğrencilerin yarısının kendileri dışında 2 kardeşi, \%9.4'ü tek kardeşi, \%22'si üç kardeşi, \%9'u dört kardeşi, \%5'i beş kardeşi vardır.

\section{BULGULAR}

Anadolu Üniversitesi'nde 9089 öğrenci örgün öğrenim görmektedir. Öğrencilerin illere göre dağılımları Şekil 1'de verilmektedir.

Anadolu Üniversitesi kayıtlarına göre üniversitede okuyan öğrencilerin 4867'si Eskişehir'de yaşamakta olduklarını belirtmişlerdir. Başka illerden üniversiteyi kazanan öğrencilerden en büyük grubu 752 öğrenci ile Ankara oluşturmaktadır. Daha sonra 568 öğrenci ile İstanbul, 275 öğrenci ile İzmir, 236 öğrenci ile Bursa gelmektedir. Karadeniz Bölgesi'nden Anadolu Üniversitesi'ni kazan öğrencilerin en çok olduğu il Samsun (73), Akdeniz Bölgesi'nden Antalya (155), Doğu Anadolu Bölgesi'nden Malatya (23), Güneydoğu Anadolu Bölgesi'nden Gazi Antep'tir (40). Anadolu Üniversitesi'nde Bayburt ve Ardahan'dan hiç öğrenci bulunmamaktadır.

$\mathrm{Bu}$ araştırma kapsamında görüşleri alınan öğrencilerin mekânsal dağılımları Şekil 2'de gösterilmektedir. 


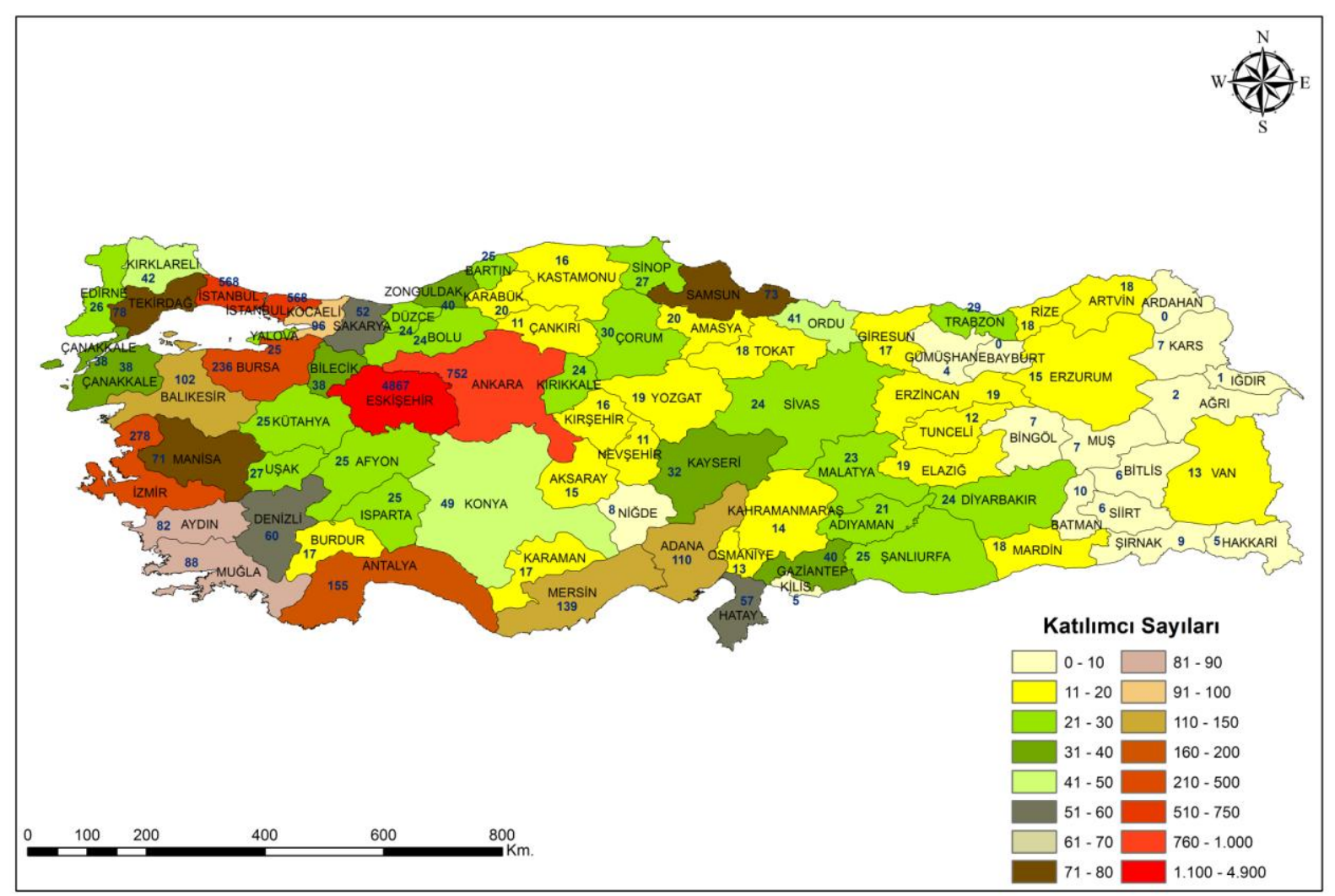

Şekil 1. Anadolu Üniversitesi örgün öğretim öğrencilerinin illere göre dağılımı

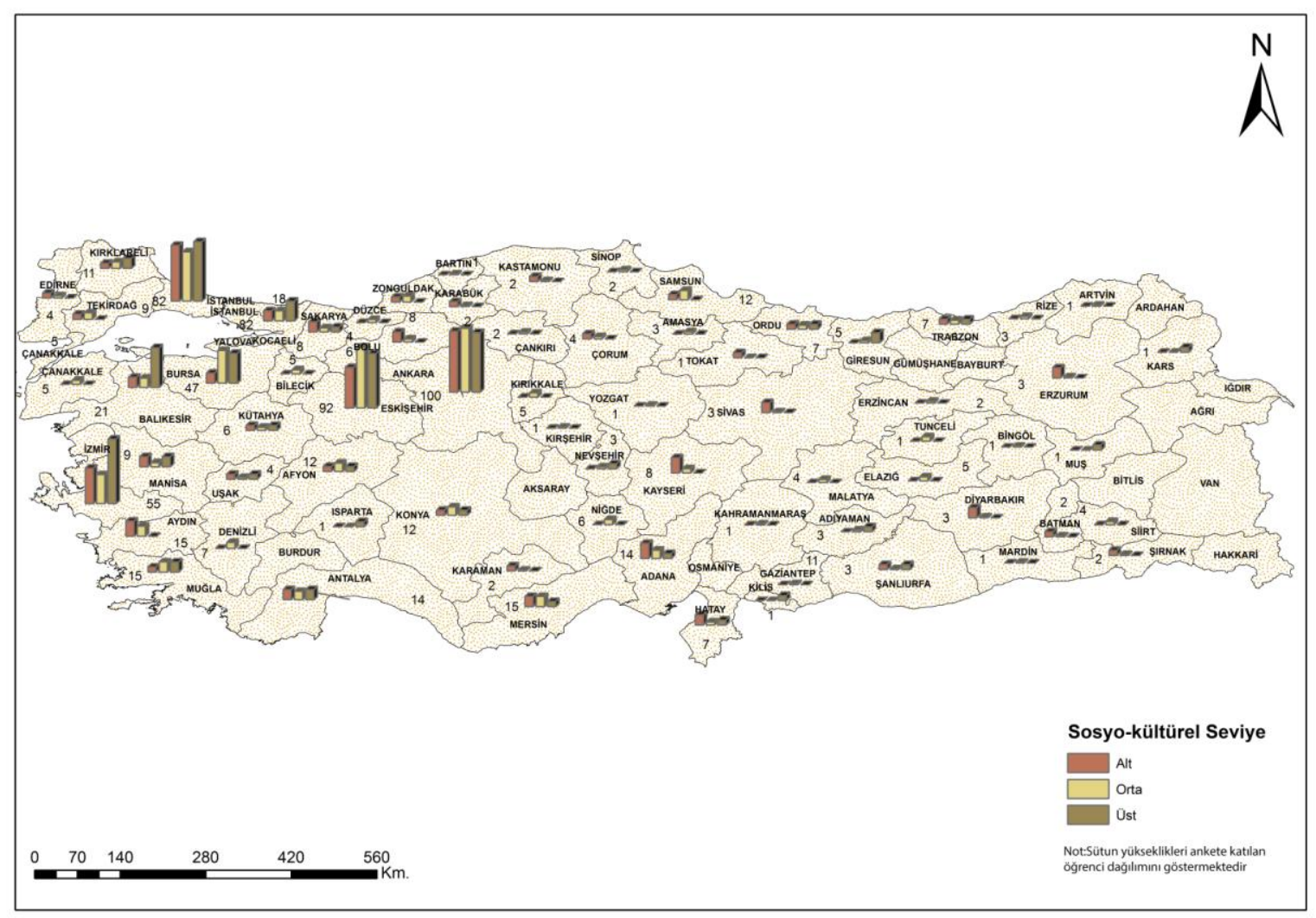

Şekil 2. Araştırmaya görüş bildiren öğrencilerin sayıları ve SKY özelliklerinin mekânsal dağılımı 
Araştırmaya görüş bildiren öğrencilerin illere göre dağılımı incelendiğinde en büyük grubu 100 kişi ile Ankara oluşturmaktadır. Daha sonra 92 kişi ile Eskişehir, 82 kişi ile İstanbul, 55 kişi ile İzmir, 47 kişi ile Bursa gelmektedir. Balıkesir (21), Kocaeli (18), Muğla, İçel ve Aydın (15), Antalya ve Adana (14) Samsun, Afyon ve
Konya (12), Kurklareli ve Gaziantep (11) diğer katılımcı sayısı yüksek olan iller arasında yer almaktadır. Toplam 69 farklı ilden Anadolu Üniversitesi'nde okuyan öğrenci ankete görüş bildirmiştir.

\subsection{Anadolu Üniversitesi öğrencilerinin sosyo-kültürel yapıları}

Öğrencilerin SKY özelliklerinin mekânsal dağılımı Şekil 3'te verilmektedir.

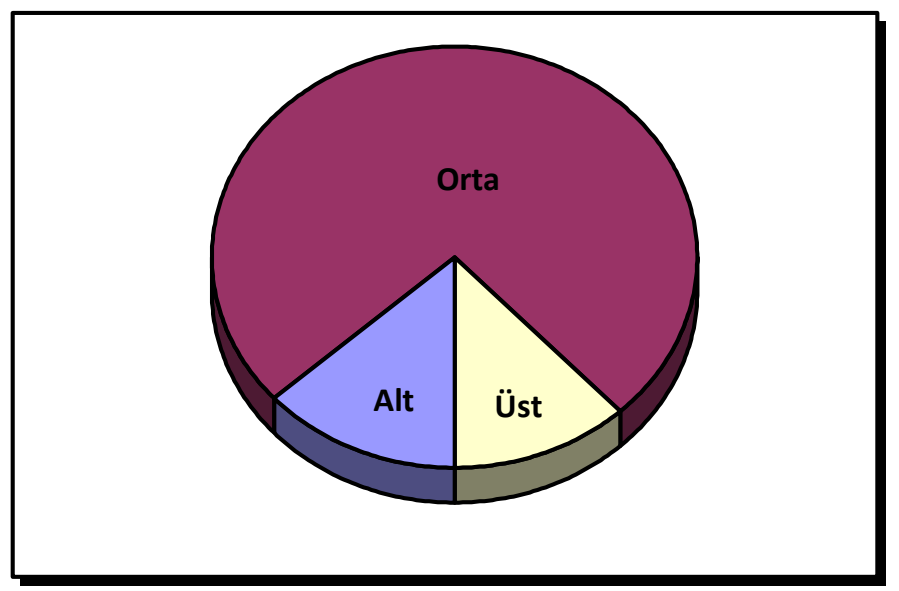

Şekil 3. Anadolu Üniversitesi öğrencilerinin sosyo-kültürel yapıları

$\mathrm{Bu}$ araştırma için geliştirilen SKY ölçeğine göre öğrencilerin \%75'i orta, \%13'ü alt ve \%12'si üst SKY grubunda yer almaktadır.

Görüş bildiren öğrencilerin üçte birinden fazla orta SKY grubunda yer almaktadır (bk. Tablo 1). Kadın öğrencilerin \%91,6'sı alt ve orta SKY grubuna dâhil iken erkek öğrencilerin alt ve üst SKY grubundaki öğrencilerin oranı \%81,7'dir. Üst SKY grubundaki erkek öğrenci oranı kadınların oranının iki katından fazladır. Cinsiyete göre SKY özellikleri istatistiksel olarak farklılık göstermektedir $\left(\mathrm{X}^{2}(2)=19.446 \mathrm{p} \leq .05\right)$.

Tablo 1. Öğrencilerin SKY özelliklerinin cinsiyete göre değişimi

\begin{tabular}{|l|l|l|l|l|l|}
\hline & & ALT & ORTA & ÜST & TOPLAM \\
\hline Kadın & $\mathrm{N}$ & 71 & 388 & 42 & 501 \\
& $\%$ & 14.2 & 77.4 & 8.4 & 100 \\
\hline Erkek & $\mathrm{N}$ & 27 & 215 & 54 & 296 \\
& $\%$ & 9.1 & 72.6 & 18.2 & 100 \\
\hline TOPLAM & $\mathrm{N}$ & 98 & 605 & 97 & 800 \\
& $\%$ & 12.2 & 75.6 & 12.1 & 100 \\
\hline
\end{tabular}

$\mathrm{X}^{2}=19.446 \mathrm{sd}=2 \mathrm{p}=.000$ 
Tablo 2. Araştırmaya görüş bildiren öğrencilerin SKY'nın bölgelere göre dağglımı

\begin{tabular}{|l|l|l|l|l|l|}
\hline & & ALT & ORTA & ÜST & TOPLAM \\
\hline Akdeniz Bölgesi & $\mathrm{N}$ & 9 & 37 & 6 & 52 \\
& $\%$ & 17,3 & 71,2 & 11,5 & 100 \\
\hline Ege Bölgesi & $\mathrm{N}$ & 18 & 103 & 28 & 149 \\
& $\%$ & 12,1 & 69,1 & 18,8 & 100 \\
\hline Marmara Bölgesi & $\mathrm{N}$ & 20 & 139 & 25 & 184 \\
& $\%$ & 10,9 & 75,5 & 13,6 & 100 \\
\hline İç Anadolu Bölgesi & $\mathrm{N}$ & 27 & 183 & 25 & 235 \\
& $\%$ & 11,5 & 77,9 & 10,6 & 100 \\
\hline Karadeniz Bölgesi & $\mathrm{N}$ & 10 & 54 & 4 & 68 \\
& $\%$ & 14,7 & 79,4 & 5,9 & 100 \\
\hline Doğu Anadolu Bölgesi & $\mathrm{N}$ & 4 & 16 & 2 & 22 \\
& $\%$ & 18,2 & 72,7 & 9,1 & 100 \\
\hline Güney Doğu Anadolu Bölgesi & $\mathrm{N}$ & 3 & 20 & 3 & 26 \\
& $\%$ & 11,5 & 76,9 & 11,5 & 100 \\
\hline TOPLAM & $\mathrm{N}$ & 91 & 552 & 93 & 736 \\
& $\%$ & 12,4 & 75 & 12,6 & 100 \\
\hline
\end{tabular}

$\mathrm{X}^{2}=11.782 \mathrm{sd}=12 \mathrm{p}=.463$

Öğrencilerin SKY'nın bölgelere göre dağılımları incelendiğinde; alt SKY'da olan üniversite öğrencilerinin oranı \%12,4'tür. Doğu Anadolu, Akdeniz, Karadeniz ve bölgelerinden gelen öğrencilerin oranı (sirasiyla \%18,2; \%17,3; \%14,7) genel ortalamanın üstündedir. Üst SKY'da olan öğrenciler için Ege $(\% 18,8)$ ve Marmara $(\% 13,6)$ bölgelerinde yaşayan öğrencilerin oranı genel ortalama olan \%12,6'nın üstündedir. Orta SKY grubunda olan öğrencilerin oranı \%75'tir. Akdeniz, Ege ve Doğu Anadolu bölgelerinden gelen öğrencilerin orta SKY grubunda olanların oranı genel ortalamanın altında, diğer bölgelerden gelen öğrencilerin ise daha yüksektir. Öğrencilerin SKY'nın bölgelere göre dağılımlarında istatistiksel olarak anlamlı bir farklılık bulunmamaktadır (X2 (2) $=19.446$ $\mathrm{p} \leq$.05) (bk. Tablo.2).

\subsection{Anadolu Üniversitesi öğrencilerinin sosyo-kültürel yapılarının fakülte ve bölüm tercihlerine etkisi}

Araştırmada öğrencilerin üniversiteyi kazanmadan önce sosyal yapı ve kültürel özellikleri hakkında bilgi toplanmıştır. Öğrencilerin bu özelliklerinin fakülte ve bölüm tercihinde etkili olup olmadığı araştırılmıştır.

Tablo 3. Anadolu Üniversitesi öğrencilerinin sosyo-kültürel yapılarının fakültelere göre değişimi

\begin{tabular}{|l|l|l|l|l|l|}
\hline & & ALT & ORTA & ÜST & TOPLAM \\
\hline İ̈F & $\mathrm{N}$ & 31 & 173 & 26 & 230 \\
& $\%$ & 13.5 & 75.2 & 11.3 & 100 \\
\hline GSF & $\mathrm{N}$ & 12 & 55 & 6 & 73 \\
& $\%$ & 16.4 & 75.3 & 8.2 & 100 \\
\hline EDEBIYYAT & $\mathrm{N}$ & 42 & 203 & 35 & 280 \\
& $\%$ & 15 & 72.5 & 12.5 & 100 \\
\hline MMF & $\mathrm{N}$ & 13 & 174 & 30 & 217 \\
& $\%$ & 6 & 80.2 & 13.8 & 100 \\
\hline \multirow{2}{*}{ TOPLAM } & $\mathrm{N}$ & 98 & 605 & 97 & 800 \\
& $\%$ & 12.2 & 75.6 & 12.1 & 100 \\
\hline
\end{tabular}

$\mathrm{X}^{2}=12.557 \mathrm{sd}=6 \mathrm{p}=.051$ 
Örneklemdeki fakültelerin hepsinde orta SKY sahip öğrencilerin oranının \%75 civarında olduğu anlaşılmaktadır (bk. Tablo 3). Genel toplamda alt ve üst SKY grubundaki öğrencilerin oranı birbirine eşittir. Ancak GSF'inde alt SKY grubundaki öğrencilerin oranı üst SKY grubundaki öğrencilerin, MMF'inde ise üst SKY grubundaki öğrencilerin oranı alt SKY grubundaki öğrencilerin oranının iki katı kadar olduğu dikkat çekmektedir. SKY farklılıklarına sahip olmalarına rağmen öğrencilerin fakülte seçimlerinde istatistiksel olarak yüzde 5 anlamlılık düzeyinde farklılık görülmemektedir $\left(\mathrm{X}^{2}(6)=12.557 \mathrm{p} \leq .05\right)$.

Tablo 4. Anadolu Üniversitesi öğrencilerinin sosyo-kültürel yapılarının bölümlere göre

\begin{tabular}{|c|c|c|c|c|c|}
\hline & & ALT & ORTA & ÜST & TOPLAM \\
\hline \multirow[t]{2}{*}{ İşletme } & $\mathrm{N}$ & 10 & 67 & 12 & 89 \\
\hline & $\%$ & 11,2 & 75,3 & 13,5 & 100 \\
\hline \multirow[t]{2}{*}{ İktisat } & $\mathrm{N}$ & 5 & 44 & 7 & 56 \\
\hline & $\%$ & 8,9 & 78,6 & 12,5 & 100 \\
\hline \multirow[t]{2}{*}{ Maliye ve ÇEKO } & $\mathrm{N}$ & 16 & 62 & 7 & 85 \\
\hline & $\%$ & 18,8 & 72,9 & 8,2 & 100 \\
\hline \multirow[t]{2}{*}{ İç mimarlık ve Baskı sanatı } & $\mathrm{N}$ & 4 & 24 & 2 & 30 \\
\hline & $\%$ & 13,3 & 80 & 6,7 & 100 \\
\hline \multirow[t]{2}{*}{ Resim, Çizgi filim animasyon ve Cam } & $\mathrm{N}$ & 8 & 27 & 2 & 37 \\
\hline & $\%$ & 21,6 & 73 & 5,4 & 100 \\
\hline \multirow[t]{2}{*}{ Felsefe ve Sosyoloji } & $\mathrm{N}$ & 12 & 56 & 8 & 76 \\
\hline & $\%$ & 15,8 & 73,7 & 10,5 & 100 \\
\hline \multirow[t]{2}{*}{ Arkeoloji } & $\mathrm{N}$ & 6 & 21 & 11 & 38 \\
\hline & $\%$ & 15,8 & 55,3 & 28,9 & 100 \\
\hline \multirow[t]{2}{*}{ Sanat tarihi ve Tarih } & $\mathrm{N}$ & 13 & 68 & 7 & 88 \\
\hline & $\%$ & 14,8 & 77,3 & 8 & 100 \\
\hline \multirow[t]{2}{*}{ Türk dili ve edebiyatı } & $\mathrm{N}$ & 11 & 50 & 4 & 65 \\
\hline & $\%$ & 16,9 & 76,9 & 6,2 & 100 \\
\hline \multirow{2}{*}{$\begin{array}{l}\text { Elektrik elektronik mühendisliği ve Bilgisayar } \\
\text { mühendisliği }\end{array}$} & $\mathrm{N}$ & 5 & 36 & 3 & 44 \\
\hline & $\%$ & 11,4 & 81,8 & 6,8 & 100 \\
\hline \multirow[t]{2}{*}{ Endüstri, Çevre, Kimya ve İnşaat mühendisliği } & $\mathrm{N}$ & 5 & 116 & 26 & 147 \\
\hline & $\%$ & 3,4 & 78,9 & 17,7 & 100 \\
\hline \multirow[t]{2}{*}{ TOPLAM } & $\mathrm{N}$ & 95 & 571 & 89 & 755 \\
\hline & $\%$ & 100 & 100 & 100 & 100 \\
\hline
\end{tabular}

$\mathrm{X}^{2}=41.567 \quad \mathrm{sd}=20 \quad \mathrm{p}=.003$

Arkeoloji dışındaki tüm bölümlerde orta SKY grubu \%75'in üzerinde bir orana sahiptir (bk. Tablo 4). Arkeoloji bölümünde ise orta SKY grubunun oranı \%55, üst SKY grubunun oranı \%29'dur. Üst SKY grubunun oranının en yüksek olduğu bölüm arkeolojidir. Arkeolojiyi işletme, iktisat, felsefe ve sosyoloji bölümleri izlemektedir. Üst SKY grubunun oranı en düşük ve alt SKY grubunun en yüksek oranları GSF'nin bölümlerinde görülmektedir. Mühendislik bölümlerinde orta SKY grupları öne çıkmaktadır. Öğrencilerin fakülte seçimlerinde istatistiksel olarak yüzde 5 anlamlılık düzeyinde farklılık görülmektedir $\left(\mathrm{X}^{2}(20)\right.$ $=41.567 \mathrm{p} \leq .05$ ).

\subsection{Anadolu Üniversitesi öğrencilerinin bazı sosyokültürel etkinliklere katılma ve izleme sıklıkları}

Anketlerde örneklemdeki öğrencilere üniversiteyi kazanmadan önce yaşadıkları şehirde ve üniversiteyi kazandıktan sonra bazı sosyokültürel etkinliklere katılma ve izleme sıklıkları sorulmuştur. 
Tablo 5. Anadolu Üniversitesi öğrencilerinin bazı sosyokültürel etkinliklere katılma ve izleme sıklıkları

\begin{tabular}{|c|c|c|}
\hline Sosyokültürel etkinlikler & $\begin{array}{c}\text { Üniversiteyi } \\
\text { kazanmadan önce } \\
\bar{x} 1\end{array}$ & $\begin{array}{c}\text { Üniversiteyi } \\
\text { kazandiktan sonra } \\
\bar{x} 2\end{array}$ \\
\hline Akraba / komşu ziyaretleri & 3.31 & 1.90 \\
\hline Bara gitme & 1.49 & 2.29 \\
\hline Bayram ziyareti & 2.06 & 1.84 \\
\hline Bireysel spor faaliyetleri yapma & 2.86 & 2.96 \\
\hline Dansa gitme & 0.59 & 0.97 \\
\hline Dini vecibelerin yerine getirilmesi & 2.56 & 2.39 \\
\hline Fotoğrafçılık & 1.19 & 1.40 \\
\hline Grup spor faaliyetleri & 1.68 & 1.63 \\
\hline Halk Oyunları & 0.51 & 0.48 \\
\hline İnternet kullanımı & 5.23 & 5.47 \\
\hline Kafeye gitme / arkadaş ziyaretleri & 4.14 & 4.48 \\
\hline Kişisel gelişim (Dans, resim, spor, vb...) & 2.66 & 2.93 \\
\hline Kitap okuma & 4.14 & 4.24 \\
\hline Kütüphaneye gitme & 2.25 & 3.47 \\
\hline Mesleki gelişim (Bilgisayar kursu, dil eğitimi, vb...) & 1.21 & 1.78 \\
\hline Öğrenci kulüplerine katılma & 0.92 & 1.75 \\
\hline Sanatçı destek gruplarına katılma & 0.62 & 0.81 \\
\hline Şiir dinletisine katılma & 0.81 & 0.83 \\
\hline Tiyatro kulüplerine katılma & 0.77 & 0.91 \\
\hline İnternet kafeye gitme & 1.17 & 1.07 \\
\hline Konserlere gitme & 1.91 & 2.39 \\
\hline Müzik dinleme & 5.45 & 5.39 \\
\hline Sinemaya gitme & 3.06 & 3.37 \\
\hline Spor karşılaşmalarını izleme & 2.65 & 2.50 \\
\hline Televizyon seyretme & 4.92 & 3.92 \\
\hline Tiyatro izleme & 1.73 & 2.07 \\
\hline Diğer (Lütfen yazınız) & 1.84 & 1.86 \\
\hline GENEL $\bar{x}$ & 2.29 & 2.41 \\
\hline
\end{tabular}

Araştırmada Anadolu Üniversitesi öğrencilerinin verilen sosyokültürel etkinliklere katılma sıklıkları sorgulanmıştır (bk. Tablo 5). Öğrencilerin verdikleri yanıtlar doğrultusunda aritmetik ortalamalar incelendiğinde üniversiteyi kazandıktan sonra sosyokültürel etkinliklere daha sık katıldıkları anlaşılmaktadır (üniversiteyi kazanmadan önce $\bar{x}=2.29$ iken üniversiteyi kazandıktan sonra $\bar{x}=2.41$ ). Öğrencilerin hem üniversiteyi kazanmadan önce hem de kazandiktan sonra en sik yaptıkları etkinlik internet kullanımı $(\bar{x} 1=5.23$ ve $\bar{x} 2=5.47)$, müzik dinleme $(\bar{x} 1=5.45$ ve $\bar{x} 2=5.39)$, kafeye gitme/ arkadaş ziyaretleri ( $\bar{x} 1=4.14$ ve $\bar{x} 2=4.48)$, kitap okuma $(\bar{x} 1=4.14$ ve $\bar{x} 2=4.24)$ ve televizyon seyretmedir ( $\bar{x} 1=4.92$ ve $\bar{x} 2=3.92)$. Öğrencilerin üniversiteyi kazandıktan sonra akraba/ komşu ziyaretleri, bayram ziyareti, dini vecibelerin yerine getirilmesi, grup spor faaliyetleri, halk oyunları, internet kafeye gitme ve spor karşılaşmalarını izleme etkinliklerini yapma sıklıklarının azaldığı belirlenmiştir. Diğer taraftan bara gitme, bireysel spor faaliyetleri yapma, dansa gitme, fotoğrafçlık, kişisel 
gelişim (dans, resim, spor, vb...), kütüphaneye gitme, mesleki gelişim (bilgisayar kursu, dil eğitimi, vb...), öğrenci kulüplerine katılma, sanatçı destek gruplarına katılma, şiir dinletisine katılma, tiyatro kulüplerine katılma, konserlere gitme, sinemaya gitme, tiyatro izleme etkinliklerinin ise sıklıklarının arttığı ortaya çıkmıştır.

Etkinlikler içinde sıklık derecesi en fazla artanlar sırasiyla kütüphaneye gitme $(\bar{x} 1=2.25$ ve $\bar{x} 2=3.47)$, öğrenci kulüplerine katılma $(\bar{x} 1=0.92$ ve $\bar{x} 2=1.75)$, bara gitme $(\bar{x} 1=1.49$ ve $\bar{x} 2=2.29)$, mesleki gelişim kurslarına katılma $(\bar{x} 1=1.21$ ve $\bar{x} 2=1.78)$ ve konserlere gitmedir ( $\bar{x} 1=1.91$ ve $\bar{x} 2=2.39$ ). Etkinlikler içinde sıklık derecesi en fazla azalanlar sirasiyla akraba/ komşu ziyaretleri $(\bar{x} 1=3.31$ ve $\bar{x} 2=1.9)$, bayram ziyareti $(\bar{x} 1=2.07$ ve $\bar{x} 2=1.84)$, dini vecibelerin yerine getirilmesi $(\bar{x} 1=2.56$ ve $\bar{x} 2=2.39)$ ve spor karşılaşmalarını izlemedir $(\bar{x} 1=2.65$ ve $\bar{x} 2=2.5)$.

\subsection{Anadolu Üniversitesi öğrencilerinin yazılı ve sözlü basında takip ettikleri konu başlıkları ve sıklıkları}

Ankette Anadolu Üniversitesi öğrencilerinin medyada takip ettikleri konular ve takip etme sıklıkları sorulmuştur. Öğrencilerin verdikleri yanitlar Tablo 6'te gösterilmektedir.

Tablo 6. Anadolu Üniversitesi öğrencilerinin yazılı ve sözlü basında takip ettikleri konu başlıkları ve sıklıkları

\begin{tabular}{|l|l|}
\hline & $\bar{x}$ \\
\hline Bilim teknik & 3.62 \\
\hline Haber & 5.39 \\
\hline Ekonomi & 3.73 \\
\hline Mesleki & 3.93 \\
\hline Politika & 4.24 \\
\hline Spor & 3.71 \\
\hline Genel Kültür Yarışmaları & 3.94 \\
\hline Sanat & 3.77 \\
\hline Dizi & 3.63 \\
\hline Magazin & 2.61 \\
\hline
\end{tabular}

Tablo 6'da görüldüğü gibi öğrenciler en sık haber programlarını $(\bar{x} 1=5.39)$, daha sonra da politika ile ilgili konuları $(\bar{x} 1=4.24$ haftada bir gün ) takip etmektedir. Bu konuları genel kültür yarışmaları ve mesleki yayınları $(\bar{x} 1=3.94$ ve 3.93 haftada bir gün) takip etmektedir.

\section{SONUÇ}

SKY hem bulunan çevreden etkilenmekte, hem de bireyler bulundukları çevreyi etkilemektedir. Türkiye'de öğrenciler üniversite sınavında aldıkları puanlar doğrultusunda üniversite, fakülte ve bölüm tercihi yapmaktadırlar. Üniversite sınavı sonunda elde edilen puanlardan sonra yapılan bölüm tercihlerde SKY özelliklerinin bir etkisinin olup olmadığı sorusu ortaya çıkmaktadır. Bu araştırma Anadolu Üniversitesi öğrencileri örneğinde SKY ile bölüm tercihi arasında bir ilişkinin olup olmadığı sorusuna yanıt aramakta ve öğrencilerin üniversiteyi kazandıktan sonra yaşamaya başladıkları şehrin ve üniversitenin sosyal ve kültürel olanaklarının sosyo-kültürel faaliyetlerine etkisini araştırmayı amaçlamaktadır. Araştırmanın evrenini Anadolu Üniversitesi öğrencileri, örneklemini de İ̈BF, Edebiyat, MMF ve GSF'leri 2. sinıf öğrencileri oluşturmuştur. Araştırma için bir SKY ölçeği geliştirilmiş, bireysel görüşlerin alındığı anket ile bu dört fakültede uygulanmış 811 öğrenci 
yanıt vermiştir. Örneklemi oluşturan öğrencilerin üniversiteyi kazanmadan önce yaşadıkları illere göre dağılışı, Anadolu Üniversitesi'nde okuyan öğrencilerin üniversiteyi kazanmadan önce yaşadıkları illerin mekânsal dağılışına paralel bir durum sergilemiştir.

$\mathrm{Bu}$ araştırma için geliştirilen SKY ölçeğine göre öğrencilerin $\% 75^{\prime}$ i orta, \%13'ü alt ve \%12'si üst SKY grubunda yer almaktadır. Cinsiyete göre SKY özellikleri istatistiksel olarak farklıllk göstermektedir. Kadın öğrencilerin $\% 90$ dan fazlası alt ve orta SKY grubuna dâhil iken erkek öğrencilerin alt ve üst SKY grubundaki öğrencilerin oranı \%80 civarındadır. Üst SKY grubundaki erkek öğrenci oranı kadınların oranının iki katından fazladır. Akdeniz ve Doğu Anadolu bölgelerinden gelen öğrencilerin SKY'nın daha düşük, Ege ve Marmara bölgelerinden gelen öğrencilerin SKY'nın daha yüksek, İç Anadolu, Karadeniz ve Güney Doğu Anadolu bölgelerinden gelen öğrencilerin ise çoğunluğunun orta SKY grubunda oldukları anlaşılmaktadır.

Öğrencilerin fakülte seçimlerinde istatistiksel olarak yüzde 5 anlamlılık düzeyinde farklılık görülmemesine rağmen GSF'inde alt SKY grubundaki öğrencilerin oranı üst SKY grubundaki öğrencilerin, $M M F^{\prime}$ inde ise üst SKY grubundaki öğrencilerin oranı alt SKY grubundaki öğrencilerin oranının iki katı kadar olduğu dikkat çekmektedir. Üst SKY grubunun oranının en yüksek olduğu bölüm arkeolojidir. Arkeolojiyi işletme, iktisat, felsefe ve sosyoloji bölümleri izlemektedir. Üst SKY grubunun oranı en düşük ve alt SKY grubunun en yüksek oranları GSF'nin bölümlerinde görülmektedir. Mühendislik bölümlerinde orta SKY grupları öne çıkmaktadır. Öğrencilerin fakülte seçimlerinde istatistiksel olarak yüzde 5 anlamlılık düzeyinde farklılık görülmektedir.

Öğrencilerin üniversiteyi kazandıktan sonra sosyokültürel etkinliklere daha sık katıldıkları anlaşılmaktadır. Öğrencilerin hem üniversiteyi kazanmadan önce hem de kazandıktan sonra en sık yaptıkları etkinlik internet kullanımı, müzik dinleme, kafeye gitme/ arkadaş ziyaretleri, kitap okuma ve televizyon seyretmedir. Öğrencilerin üniversiteyi kazandıktan sonra akraba/ komşu ziyaretleri, bayram ziyareti, dini vecibelerin yerine getirilmesi, grup spor faaliyetleri, halk oyunları, internet kafeye gitme ve spor karşılaşmalarını izleme etkinliklerini yapma sıkliklarının azaldığ 1 belirlenmiştir. Diğer taraftan bara gitme, bireysel spor faaliyetleri yapma, dansa gitme, fotoğrafçılık, kişisel gelişim (dans, resim, spor, vb...), kütüphaneye gitme, mesleki gelişim (bilgisayar kursu, dil eğitimi, vb...), öğrenci kulüplerine katılma, sanatçı destek gruplarına katılma, şiir dinletisine katılma, tiyatro kulüplerine katılma, konserlere gitme, sinemaya gitme, tiyatro izleme etkinliklerinin ise sıklıklarının arttığı ortaya çıkmıştır. Etkinlikler içinde sıklık derecesi en fazla artanlar sırasıyla kütüphaneye gitme, öğrenci kulüplerine katılma, bara gitme, mesleki gelişim kurslarına katılma ve konserlere gitmedir. Etkinlikler içinde sıklık derecesi en fazla azalanlar sırasiyla akraba/ komşu ziyaretleri, bayram ziyareti) dini vecibelerin yerine getirilmesi ve spor karşılaşmalarını izlemedir.

Anadolu Üniversitesi öğrencilerinin medyada takip ettikleri konular ve takip etme sıklıkları incelendiğinde en sik haber programlarını, daha sonra politika ile ilgili konuları takip ettikleri ortaya çıkmaktadır.

Araştırmaya göre öğrencilerin SKY özellikleri üniversite, fakülte ve bölüm tercihlerinde etkili olabilmektedir. $\mathrm{Bu}$ araştırmanın dikey araştırma yöntemi ile tekrarlanmasında yarar bulunmaktadır. Öğrencilerin üniversiteyi kazandıkları yıl SKY özellikleri belirlenmelidir. Bir de aynı gruba mezun olmadan önce ki SKY özellikleri sorulmalıdır. Böylece üniversitelerin ve üniversite okunan şehirlerin öğrencilerin SKY özelliklerinde ne kadar ve ne yönde etkili olduğu konusunda daha sağlıklı sonuçlar elde edilebilir. 


\section{Kaynaklar}

Abbas, Z., (2007), Makedonya'da Ulahların Sosyo-Kültürel Yapısı, Hacettepe Üniversitesi Sosyal Bilimler Enstitüsü Sosyoloji Anabilim Dalı, Basılmamış Doktora Tezi.

Aslan, K., (2001), “Eğitimin Toplumsal Temelleri", Balıkesir Üniversitesi, Sosyal Bilimler Dergisi, Say1 5.

Aytekin, A., (2005), Meslek Seçimini Etkileyen Sosyoekonomik ve Kültürel Faktörler Isparta Örneği. Süleyman Demirel Üniversitesi, Sosyal Bilimler Enstitüsü, Basılmamış yüksek lisans tezi, Isparta.

Çakır, H.K., (2006), Konut Alanları Yer Seçiminde Sosyal Yapının Rolünün Saptanmasına İlişkin Sistematik Bir Yaklaşım: Edirne Kaleiçi, Kaledışı Ve Yeni Yerleşme Alanları Örneği, Trakya Üniversitesi, Fen Bilimleri Enstitüsü, Basılmamış Doktora Tezi.

Eroğlu, C., (1996), Türk Sosyo-Kültürel Yapısı İçerisinde Manas Destanı, Sakarya Üniversitesi, Sosyal Bilimler Enstitüsü, Basılmamış Yüksek Lisans Tezi.

Karasar, N., Hakan, A., Can, G., (1999), “Anadolu Üniversitesi öğrencilerinin sosyokültürel ve sosyo-ekonomik özellikleri ile beklenti ve sorunları", T.C. Anadolu Üniversitesi yayınları ; no. 1097. Açıköğretim Fakültesi yayınları; no. 602, XXI, 409 s.

Kılınç, A. (2007), Üniversite seçiminde öğrenci yönelimlerini etkileyen faktörler. Marmara Üniversitesi Fen Bilimleri Enstitüsü Yayınlanmamış Yüksek Lisans Tezi. Danışman: Yrd. Doç. Dr. Mustafa Meral

Pehlivan Baykara, K. (2008), “Sinıf öğretmenlerinin sosyo kültürel özellikleri ve öğretmenlik mesleğine yönelik tutumları üzerine bir çalışma" Mersin Üniv. Eğitim Fak. Dergisi 4 (2) $151-168$

Sertelin, Ç., (2003), Ebeveyn Tutumlarının Sosyo Kültürel Yapı ve Aile Fonksiyonları İle İlişkisi. İstanbul Üniversitesi, Sosyal bilimler Enstitüsü, Basılmamış yüksek lisans tezi, İstanbul.

Toğrul, İ., (2010), Azerbaycan'da Üniversite Gençliğinin Sosyokültürel Yapısı, Basılmamış Doktora tezi İstanbul Üniversitesi, İstanbul. 